\author{
BARBARA GUTKOWSKA \\ (D) https://orcid.org/0000-0003-0545-6253 \\ Uniwersytet Śląski w Katowicach \\ Katowice
}

\title{
„Gombrowicz jest moją zmorą"* . Dziennikowe zmagania Sławomira Mrożka z Witoldem Gombrowiczem
}

\author{
"Gombrowicz haunts me." \\ Sławomir Mrożek's diary struggles with Witold Gombrowicz
}

\begin{abstract}
The autobiographical works of Sławomir Mrożek, which include his extensive diaries from the years 1962-1989 and large volumes of correspondence, continue to be open to new readings. Since the key, and until now undescribed problem in the meta-literary layer is the relation to Witold Gombrowicz as an artist and as a human being, the paper analyses and interprets, from a historical literary and comparative point of view, the multi-annual polemics with the aesthetic and philosophical views of the author of Ferdydurke, which Mrożek conducted in his diaries from 1965 to 1987. The process-based nature of the author's references is emphasised: from respectful acceptance to the decisive overcoming of Gombrowicz's influence, ending in the opening of Mrożek towards metaphysics, absent from his master's worldview. The particular role of Gombrowicz's work is pointed out as a mirror for Mrożek, where Mrożek's reflection on himself as an artist and on his own art took shape and gained confidence.
\end{abstract}

Keywords: Mrożek, Gombrowicz, autobiographism, polemics

Dążeniem Gombrowicza było trwałe oddziaływanie na sposób myślenia czytelników, krytyków, opinii publicznej przez naruszanie porządków ich mentalnego i emocjonalnego świata oraz pobudzanie do intelektualnego zmierzania się z zastaną rzeczywistościa - wbrew obowiązującym zasadom i schematom. Kiedy konstatował u schyłku życia: „Nie chcę być falą, która

* Mrożek 2003, 175. Odnotować w tym miejscu należy, że relacje pomiędzy dziennikami Mrożka i Gombrowicza opisane zostały psychoanalityczno-filozoficznie w książce S. Wróbla (Wróbel 2015), a na podstawie tomów korespondencji Mrożka z A. Tarnem, S. Lemem, J. Błońskim i W. Skalmowskim omawiał je T. Bocheński (Bocheński 2012). 
uderza o skałę, chcę być (w Drienniku) wodą, która sączy się, przecieka..." (Gombrowicz W. 1992, 116), opisywał strategię swojej zwycięskiej batalii nie tylko o wysoka pozycję w świecie literackim, ale przede wszystkim o rolę intelektualnego stymulatora, rozrusznika myśli, bezwzględnego tropiciela i demaskatora nonsensów, zakłamań, wygodnych racjonalizacji, bezużytecznych skamielin tradycji, podejrzanych autorytetów. Był pewien skuteczności swej metody już w pierwszej połowie lat 60., gdy na stwierdzenie Rity Gombrowicz, że pisarstwo Mrożka współgra z jego twórczością, odpowiedział: „To nic dziwnego, bo ja jestem ojcem polskiej literatury" (Gombrowicz 2014, 112). Kolejne pokolenia pisarzy i badaczy potwierdzały (i potwierdzaja do tej pory), jak trwały i wyrazisty ślad pozostawił po sobie we współczesnej literaturze oraz sposobie ujmowania polskiej rzeczywistości wobec świata ${ }^{1}$. Jednak w przypadku twórczości Sławomira Mrożka kwestia ta jest o tyle bardziej złożona, że wpływy Gombrowicza zostały w niej zauważone, zanim on sam - „produkt okresu, kiedy więcej powinno się i mogło wiedzieć o trzeciorzędnym pisarzu Radzieckiej Republiki Kazachstanu niż o Gombrowiczu” (Mrożek 2003, 173) - poznał jego utwory. Toteż ta niemożliwa do jednoznacznego wyjaśnienia równoległość myślowa aktów kreacji, jak pisał: „,niewątpliwa praobecność Gombrowicza we mnie" (Mrożek 2003, 173), była dla niego szczególnie frustrująca, gdy okazało się, że opublikowana w 1966 roku Operetka Gombrowicza podejmuje identyczną problematykę formy, stroju, mody i rewolucji jak jego Krawiec, napisany w roku 1965. Chociaż Stanisław Lem pocieszał Mrożka, że ta twórcza koincydencja, czyli „przechwycenie” pomysłu, jest „sprawą samej ilości głów rozmyślających” (Lem, Mrożek 2011, 625), można tę sytuację interpretować Bloomowskim „lękiem przed wpływem” i łatwo wskazać także w dzienniku Mrożka poszczególne etapy rewizyjne, świadczące o wyzwalaniu się od inspiracji „artysty - ojca”2. Zwłaszcza że początki jego emigracji łączyły się bezpośrednio z nawiązaniami do twórczości Gombrowicza, która podejmowała nie tylko istotny również w utworach Mrożka problem polskości, uwięzionej w stereotypach zakłamujących relacje ze współczesną rzeczywistościa, ale i próbę odpowiedzi na pytanie o miejsce człowieka (będącego polskim pisarzem) w konfron-

\footnotetext{
${ }^{1}$ Najnowsze ujęcie tego tematu można znaleźć w artykułach autorstwa m.in. Jerzego Jarzębskiego, Andrzeja Zieniewicza, Mariana Bieleckiego, Wojciecha Śmiei, zamieszczonych w zredagowanej przez Józefa Olejniczaka pracy zbiorowej Præed i po. Witold Gombrowicz (Olejniczak 2019).

2 O Bloomowskim, agoniczno-dialogicznym stosunku Mrożka do Gombrowicza w odniesieniu Krawca do Operetki zob. M. Bielecki (Bielecki 2010).
} 
tacji z zachodnioeuropejskością i niewątpliwie stała się dzięki temu zasadniczym punktem odniesienia w wyzwalaniu się Mrożka z polskiej formy:

Jeśli myślę teraz o sobie w przyszłości, to myślę o tym, co ma wyniknąć ze zderzenia się mnie, człowieka Polaka, z całym światem, a nie, jak dotąd, mnie, Polaka - człowieka z Polski. W tym być może naśladuję Gombrowicza (jakie tam być może, na pewno), ale po co wreszcie Gombrowicz żyje, jeżeli nie po to, żeby inni myśleli (13 października 1963) (Mrożek 2010, 45).

Fascynacja Gombrowiczem nie dotyczyła jednak wyłącznie literatury, gdzie w naturalny sposób, także za sprawą pokoleniowego pierwszeństwa, autor Pamiętnika z okresu dojrzewania zajął pozycję niekwestionowanego mistrza, wobec którego jego następcy muszą się w konkretny sposób określić: wejść na ścieżkę kontynuacji albo formalnego i problemowego starcia. Dlatego kiedy Mrożek napisał po latach:

bez Gombrowicza byłbym ubogi. Ale z Gombrowiczem nie jestem soba. Nacisk Gombrowicza jest silny i kłopotliwy, ale właśnie przez to zbawienny. Bo - jeśli chce się być - wymaga równie silnego odporu. Jest to więc nacisk stwarzający (Mrożek 2003, 174-175)

to znaczy, że cały czas widział w nim wzorzec artysty stawiającego innym wyzwanie, któremu on sam chciał i musiał sprostać, aby zaistnieć jako jasno określone „ja”, a więc być sobą. Przeglądał się w Gombrowiczu i jego twórczości jak w lustrze, pomocnym w analizie dostrzeżonych dzięki niemu swoich atutów i niedomyśleń, czyli kreowaniu artystycznej tożsamości. Niezachwiana pewność siebie Gombrowicza była przedmiotem niezmiennego szacunku i podziwu Mrożka od ich pierwszego spotkania we Włoszech:

Dzisiaj przyjechał Gombrowicz. Pan Gombrowicz, a po włosku Padrone. Każde zjawisko można interpretować rozmaicie. Ja zostanę przy „Pan”.

Zrozumiałem, że go nie lubią. Albo odwrotnie. Nie lubia go, bo sa przez niego ujarzmiani, czują siłę, przemoc. Nikt tego nie lubi.

Zaledwie przyjechał, widział się z nami nie dłużej niż pół godziny. Przez niego nie śpię teraz w nocy.

A w ogóle ... siła, co to jest?

Tacy, co czują siłę, interesują mnie szczególnie, bo oczywiście chciałbym takim zostać. Czasem wydaje mi się, że cała moja nędza, zakurzenie, ciamkanie, to tylko dlatego, że zgodziłem się żyć pod kocem. Wstydzę 
się mojego istnienia. Nie mam odwagi stać się żyjącym faktem, żyję na pograniczu bezwładu i zawstydzenia.

$(\ldots)$

Padrone. Wielka ambicja, wielkie obowiązki, wielka bezwzględność. A co do mnie, tylko jedno jest mi podrzędne, że ja nie chcę być podrzędny.

Jestem tu już od dawna na terenie samego siebie i wszystko musi się rozstrzygnąć.

Padrone to moje dążenie do tożsamości, a nie rozmazanie w niczym (4 czerwca 1965) (Mrożek 2010, 213-214).

Gombrowicz nadal mnie zadziwia. (...) Niewatpliwie jest jednym z najważniejszych spotkań w moim życiu (8 czerwca 1965) (Mrożek 2010, 215).

Spotkanie to odbywało się w szczególnych okolicznościach psychologiczno-egzystencjalnych dla autora Stonia. Przebywał wówczas od dwóch lat na emigracji, będącej w założeniach papierkiem lakmusowym artystycznej wartości jego dzieł i sprawdzianem pisarskich umiejętności poza okiem peerelowskiego cenzora, starał się znaleźć nową formułę dla swej twórczości: uniwersalna, uwolnioną od gorsetu satyry i politycznych aluzji, czytelnych przede wszystkim dla polskiego odbiorcy. Dla pisarza, który stwierdzał, że jego „prawdziwa, poważna biografia wewnętrzna jest bardzo krótka, nie więcej niż trzy, cztery lata (11 lipca 1965)" (Mrożek 2010, 228), bezpośredni kontakt z Gombrowiczem - który pomimo wieloletniej i trudnej argentyńskiej emigracji, wierny sobie zwycięsko wkroczył na literackie salony Europy - zintensyfikował myślenie na temat artystycznego sposobu istnienia, mocnego zaznaczenia w sztuce swojej indywidualności, relacji ze światem podbudowanych przeświadczeniem o wadze i wartości swych poglądów. Toteż w bezsenną - za sprawa Gombrowicza - czerwcową noc 1965 roku rozpoczął Mrożek w swoim dzienniku długoletnią konfrontację nie tylko z Gombrowiczem pisarzem, lecz także Gombrowiczem człowiekiem: Panem, Padrone i Szefem, jak go później w dziennikowych zapiskach będzie nazywał, ponieważ widział w nim „pisarza całkowitego”3, którego jedyną możliwością życia i samoreali-

3 Określenie Mrożka w odniesieniu do Tomasza Manna, lecz oddające także specyfikę twórczości Witolda Gombrowicza. Zob. Błoński, Mrożek 2004, 237. Nadto w samym Dzienniku można naleźć notatkę, w której Mrożek dokonuje zestawienia obydwu pisarzy: „Gombrowicz był ostatni (?), który mówił o sztuce. (...) myślał o sztuce poważnie, naprawdę, jak Tomasz Mann. Może tak trzeba, może tego mi zabrakło, może do tego wrócić... (21 kwietnia 1984)" (Mrożek 2013, 486-487). 
zacji była literatura: „u niego nie ma «życia» $\mathrm{i}$ «sztuki», z pierwszego wprost w drugie i kto wie, czy teraz nie tak tylko można, czy nie minął okres «literackości» (3 stycznia 1965, piątek)" (Mrożek 2010, 576).

W przywołanym wcześniej fragmencie dotyczącym ich pierwszego spotkania widać wyraźnie, jak mocne wrażenie wywarł Gombrowicz na Mrożku, który jego siłę i wielkość (ambicji, obowiązków i bezwzględności) zestawiał z własnym wstydem podrzędności, fragmentaryczności oraz poczuciem niemocy i niedookreślenia. Ubolewał nad brakiem jasności swoich wypowiedzi, strachem i ucieczkami przed życiem i ludźmi, w odróżnieniu od Gombrowicza precyzyjnie i jasno formułującym myśli, otwartym na kontakt z innymi, z którymi nieustannie podejmował grę, pewny swojej wygranej. A tego poczucia Mrożek był zupełnie pozbawiony, stwierdził także cztery lata później: „Gombrowicz jest, ja ciagle nie jestem nawet pewien, czy jestem (1 stycznia 1969)" (Mrożek 2010, 575). Wspominając natomiast po 25 latach, w 1987 roku, to samo spotkanie, pisał Mrożek o swoim ówczesnym zdruzgotaniu przez „pańskość Padrone”, przy którym czuł się poniżony jak „lumpenproletariusz i nędzny arywista (12 grudnia 1987)” (Mrożek 2013, 710) bez artystycznej przyszłości. Oceniał to ówczesne odczucie jako efekt - stale mu towarzyszącej - naiwności i wiary

w pozory, tym bardziej, im bardziej natrętne i staranniej konstruowane przez każdego, kto się w nie uzbraja. Tak, ze mną mu się udało, jeżeli nie na zawsze, to tylko dlatego, że go przeżyłem. Ale to nie jest ani jego porażka, ani moje zwycięstwo (12 grudnia 1987) (Mrożek 2013, 711).

W klamrze lat 1965-1987 zamykają się zmagania Sławomira Mrożka z Wielkim Poprzednikiem, który wielkim dla niego pozostał, ale o którym w ich finale mówi już bez kompleksu niższości, jak równorzędna osobowość twórcza. Dzięki Gombrowiczowi i jego twórczości dokonał bezlitosnej autowiwisekcji, pomocnej w zarysowaniu projektu sztuki, zgodnej z jego zainteresowaniami i predyspozycjami osobowości. Z ,geometry bez bagażu” kulturowego, wyniesionego z rodzinnego domu, ze „sztuczkomistrza”4 tryumfującego zresztą wówczas od dawna na deskach teatrów całego świata - stał się w końcu we własnych oczach twórca pewnym swego światopogladu artystycznego, świadomym siebie, w nieuniknionych ponowieniach podjętych z przeszłości wzorów pozostawiającym swój indywidualny, niepodrabialny ślad.

${ }^{4}$ Samookreślenia Mrożka zaczerpnięte z: Błoński, Mrożek 2004, 83. 
Kluczowym momentem w procesie dochodzenia Mrożka do samego siebie była śmierć Gombrowicza w lipcu 1969 roku. Bezpośredni kontakt z pisarzem zastapiły Mrożkowi wielokrotnie odnotowane w Drienniku lektury Dįiennika Gombrowicza, przy okazji których pojawiały się obszerne odniesienia do twórczości, artystycznej filozofii oraz do listów od mistrza, z których dwa zostały przez niego fragmentarycznie zacytowane. W pierwszym Gombrowicz, czyniący z walki o siebie sposób na życie i pisanie, odmawiał młodszemu koledze „braku woli narzucania się (30 grudnia 1967, sobota)" (Mrożek 2010, 499), czym sprowokował Mrożka do zastanawiania się, czy możliwe jest z tego braku stworzenie własnej filozofii, teorii. W drugim, przywołanym w 1984 roku - zakwalifikował twórczość Mrożka do „strefy pośredniej”, zarzucał jej bowiem: „miękkość”, „publiczkowatość”, „niemożność utrzymania się na poziomie”, „rzeczy znakomite obok płaskich”, „brak stanowczości, ostrości, oczyszczenia (11 kwietnia 1984)" (Mrożek 2013, 486-487). Rozmyślania nad starymi listami pięć lat po śmierci Gombrowicza świadczą znamiennie o jego nieprzerwanej obecności w myśleniu Mrożka o sobie i literaturze. Chroniczny malkontent, w dalszym ciagu niezadowolony ze swojego pisania i od dwudziestu lat wciąż poszukujący własnej formuły, stale odnosił się do tej Gombrowiczowskiej, która była mu - szczególnie wrażliwemu na formy nieodpowiadające rzeczywistości, zmarłe - najbliższa, chociaż już w 1969, tuż po śmierci autora Ferdydurke, poddał ją bezwzględnej krytyce, przybierającej formę artystycznego manifestu:

Odrzucam jego Młodość - Dojrzałość. To nie najważniejsze.

Odrzucam jego Międzyludzkie. To oczywistość, nie najważniejsze.

Odrzucam jego Wolę, wyższość i niższość - to nie o to chodzi.

Jemu to służyło, taki był, był graczem, szachistą - mnie szachy nudza. Był jednakże stoikiem, mnie stoicyzm nie bawi.

On o tym wszystkim wiedział i starał się tym wszystkim nie być. A mnie nieustanna dialektyka nudzi: najpierw być czymś, potem temu zaprzeczać. Rodzaj ping-ponga, sam ze soba. Mina i kontrmina. (...)

Jest w nim irytujący element towarzyski, element społecznego. Jest w nim za dużo społecznego, układów odniesienia. (...) On był solidny i miał kilka punktów oparcia we wszechświecie. Gdzieś na czymś solidnym opierał się solidnie. Dlatego ludzie do niego lgnęli. Dawał im poczucie solidności. Rzeczywistości.

Tymczasem ja czuje prawdę inna, nakaz, imperatyw: porąbać resztki budowy, rynsztunku, okrętu, a raczej czy rąbać, nie bronić już, jeżeli owe 
gmachy, wymalowane na płóciennej zastawce, same mi butwieją pomóc wiatrowi, kiedy porywa landszaft. (...)

Gombrowicz osobiście pokonywał mnie i miażdżył. Bo nie będąc z jego pola, stałem na nim jedną nogą, wahająco. On stał obiema na swoim.

Forma - też oczywistość. Ale czy w jego walce z forma, w jego zapamiętaniu formy nie był właśnie jej więźniem? (6 września 1969, Paryż) (Mrożek 2010, 615).

Gombrowicz opracował wzór, formułę, która okazała się zadziwiająco pojemna, skuteczna, materia - okazało się - układa się według tej matematyki (16 października 1973) (Mrożek 2012, 172).

- dlatego z taką łatwością wszystkim ją narzucał. Ukazał schemat funkcjonowania świata międzyludzkiego, oparty na dialektyce form młodości i dojrzałości, niższości i wyższości - pochodnych zasadniczej opozycji kultury/porządku i natury/chaosu. Z formy - z którą wcale nie walczył, tylko nia manipulował - uczynił fundament swego światopoglądu. Według Mrożka takie przykrojenie rzeczywistości do jednego układu zbytnio ją upraszcza $i$ jest intelektualnie jałowe:

Zmienianie jednej formy na druga - a cóż to mnie obchodzi? Co mnie obchodzi stryjek, który zmienił siekierkę na kijek? (...)

Gombrowicz mógł być zgodny z jego sztuką, ponieważ jego sztuka była łatwiejsza niż moja (jej projekt). Gombrowicz nie chciał niczego niemożliwego.

Może dlatego, że chcę niemożliwego („niemożliwego”), nie robię tego, co możliwe? (12 października 1969) (Mrożek 2010, 634, 650).

Mrożek permanentnie przebywał w fazie projektowania swojej literatury i poszukiwał właściwej problematyki i formy jej wyrażenia, dlatego całościowy, monolityczny, nasycony i nasycający innych sobą Gombrowicz ze swoimi dziełami stał się jego zasadniczym i negatywnym polem odniesień. Naprzeciwko monumentalnego „Ja" staną twórca świadomy swego rozdrobnienia, fragmentaryczności i poznawczego nienasycenia, ujmujący tę ontyczną odmienność w stwierdzeniu: „Gombrowicz: ciagłość i jednolitość. Ja: kropka, kreska. Jestem jak alfabet Morse'a (12 marca 1972)" (Mrożek 2012, 95). Źródła tej różnicy dostrzegał w fundamentalnym założeniu przez Gombrowicza nieistnienia absolutu, który autor Ferdydurke zastapił światem, co sprawiło, że nie musiał nieustannie zderzać się, jak Mrożek, z jego brakiem, z nieuchwytnością „niemożliwego”, uniemożliwiającym stworzenie 
spójnej całości. „Ja: urodziłem się z głodem absolutu (12 marca 1972)" (Mrożek 2012, 95) - stwierdzał i dostrzegał (obok Gombrowiczowskiego schematu ujmowania świata) potencjalność istnienia innych układów, nieopartych na - problematycznym według niego - dowartościowaniu "Ja". Łaknął absolutu, $\mathrm{z}$ coraz większym dystansem oceniał toczoną w literaturze i w życiu walkę Gombrowicza o wybitność. Zobaczył w niej w końcu, bo „Nad tym Gombrowiczem nigdy nie dość zastanawiania się (14 grudnia 1987)" (Mrożek 2013, 712):

Jego olbrzymi strach przed tym, czego nie da się kontrolować.

Jego naczelna ambicja, wysiłek, dążenie - to wyhodować sobie ślimaczą skorupkę, która by go chroniła, najrozpaczliwsza walka o ,ja”, „JA!”. Jego dramat, jego napięcie, jego dynamika, to, że będąc tak wybitny, nie mógł oczywiście uznać - nigdy - że to mu się nie udało (czy miał sekretne wątpliwości, że to jest w ogóle możliwe?), że to mu się udaje, stąd nieustający wysiłek. Chyba był bardzo zmęczony.

Tęsknił za „krwistymi befsztykami” (Szekspir, inni dawni), marzył coś o ,zieloności”, a sam wysuszał się starannie i desperacko.

Walczył o „pańskość", ale czy nie był w tym małostkowy i wcale nie pański? (12 grudnia 1987) (Mrożek 2013, 710).

Burząc innych, umacniał siebie, tak zwane panowanie („narzucanie się”) to była jego mania. Nie mógł bliźnich swoich zostawić w spokoju. Nie wiem, jak Sokrates, ale jakkolwiek o Gombrowiczu myślę, z którejkolwiek strony - zawsze na to mi wychodzi, że młodzieńczość była jego cechą. Młodzieńczość - po polsku brzmi to ładnie (że niby świeżo i młodo). Adolescent nie brzmi aż tak pochlebnie, a najlepiej pamiętać, że młodzieniec to znaczy nierozwinięty, a patrząc od strony dorosłego: niedorozwinięty (14 grudnia 1987) (Mrożek 2013, 712).

Uderza stylistyka użyta do oceny podziwianego przecież nadal mistrza. Hiperbolami: „olbrzymiego strachu”, „najrozpaczliwszej walki”, „nieustającego wysiłku” zestawionymi z ich efektami: „hodowaniem ślimaczej skorupki” oraz „starannym i desperackim wysuszeniem” prowadzi Mrożek do ironicznej konkluzji, sprowadzającej Gombrowicza do - tak bardzo przecież przez niego gloryfikowanej - młodzieńczości, czyli niedojrzałości, która dla baczącego na znaczenia słowa krytyka tożsama jest z niedorozwojem, a więc niedopełnieniem, brakiem. W jego ujęciu Gombrowicz jest pisarzem „całkowitym" wyłącznie na własnym terenie, poza nim pozostawia uczcie niedostateczności, nienasycenia. Apoteozę młodości widzi więc Mrożek jako 
ograniczające uproszczenie i odwrócenie się od tego, co rzeczywiście istotne, a o czym pisał po śmierci Mary, swojej pierwszej żony:

I teraz powtarzam. On nie ma racji. Ręka Mary, gdzie jej do sławionej przez G. Albertynki, gdzie do młodości i piękności, zdrowia. A jednak ja w tej ręce widzę więcej niż - obym się nie zagalopował. Nie rozumiem, dlaczego ciało piękne, zdrowe, które tak lubię, dlaczego żarcie i miłość dennie fizyczna, które mnie tak fascynuja (tak, rozumiem jednak Gombrowicza), gdzieś jednak ustępują tej zmęczonej ręce? Dlaczego to goraco i zdrowie ciała, które chce, które jest, które się spełnia, musi obawiać się tamtej ręki, nie odwrotnie? (19 grudnia 1969) (Mrożek 2010, 688).

Podszytej szyderstwem i rozpaczą apologii Albertynki konfrontował śmierć i nicość, twierdził, że: „Tylko nicość jest poważna (cytuję sam siebie). Coś jest niepoważne. „Cosia” nie ma. (...) Nie traktować poważnie niczego, co jest (12 października 1969)" (Mrożek 2010, 650-651). Ostatnim zdaniem najmocniej przeciwstawił się Gombrowiczowi, „królowi rzeczywistości”, poświęcającemu najwięcej stron problemowi urzeczywistniania „ja” wśród międzyludzkiego. Mrożkowi - „metafizycznemu malkontentowi” (19 grudnia 1973, State College) (Mrożek 2012, 209), „absolutczykowi”, „,tkniętemu szaleństwem Nienasycenia"5 - z jego dystansem do rzeczywistości i ludzi oraz narastającym głodem Absolutu coraz bliżej było do Witkacowskiej koncepcji Tajemnicy Istnienia, dlatego nicość, śmierć, przypadek i brak uznał za najważniejsze tematy literatury. Otwierając się na niewiadome, niejasne, niewyrażalne, nie odchodził przy tym od tego, co od początku było atutem jego pisarstwa i w czym również był bliski Witkacemu:

Witkacy czuł świat, wiedział, co się w nim dzieje, podczas gdy Gombrowicz czuł najbliższe tylko otoczenie. O stanie świata nie miał pojęcia. Był o wiele mniej historyczny, socjalny, społeczny czy polityczny niż Witkacy. Był w ogóle ahistoryczny (14 grudnia 1987) (Mrożek 2013, 713).

Polityka, historia, mechanizmy socjologiczne zawsze stały w centrum zainteresowań Mrożka, reagującego na sygnały słane przez współczesną mu rzeczywistość w utworach literackich, w publicystyce, a po latach okazało się, że również w potężnych tomach listów do przyjaciół oraz Dzienniku, który pod wpływem Driennika Gombrowicza? - pisany był od samego początku

\footnotetext{
5 Samookreślenia Mrożka (Mrożek, Skalmowski 2007, 65).
} 
z myślą o odbiorcy, a więc do druku: „Ustalmy więc uczciwie: to, co zaczynam, może czytać każdy. (...) Koniec przedmowy (25 października 1962, piątek)" (Mrożek 2010, 6-7). Fascynacja jednocześnie podziwianym i odrzucanym Gombrowiczem sprawia, że stał się on - obok autora - najbardziej i najczęściej eksponowanym bohaterem jego rozważań. To jemu zawdzięczał instrumentarium, umożliwiające często bezlitosną autoanalizę, i kiedy pisał o Gombrowiczu, pisał Mrożek w istocie o sobie, stawał się dla siebie samego bardziej wyrazisty. Świadomy siebie, czyli swojego rozproszenia i fragmentaryczności, przeciwstawił silnemu ,ja” Gombrowicza „świadectwo nietożsamości”, wzmocnione po latach w 2006 roku wyznaniem w Baltazarze:

Nazywam się Sławomir Mrożek, ale na skutek okoliczności, które zaszły w moim życiu cztery lata temu, moje nazwisko będzie znacznie krótsze: Baltazar.

$(\ldots)$

Zmieniając nazwisko i podpisując się „Baltazar”, przyznaję się otwarcie do niedoskonałości. Odtąd nie można mnie chwalić ani ganić za nic, co napisałem przed afazją, ponieważ tamten człowiek nie istnieje (Mrożek 2004, 9 i 248).

Życie samo potwierdziło pogląd Mrożka o przewadze niepewności, płynności i przypadku nad formą, która jest zawsze skończona. Gombrowicz zastygł w urzeczywistnianym autokomentarzami kształcie, podczas gdy Mrożek ciagle myślał i pisał o sobie jako możliwości otwartej na nieznane. Osobni i samowystarczalni stali się awersem i rewersem wybitnej literatury.

\section{Bibliografia}

Bielecki M., 2010, „Stowem, bardzo lubie ulegaí wplywom”. O Stawomira Mrożka dialogach z Witoldem Gombrowiczem, w: tegoż, Historia - dialog - literatura. Interakcyjna teoria procesu historycznoliterackiego, Wrocław.

Błoński J., Mrożek S., 2004, Listy 1963-1996, wstęp Nyczek T., Kraków.

Bocheński T., 2012, Mrożek jako krytyk Gombrowicza, „Teatr”, nr 2.

Gombrowicz R., 2014, O tym, jak Mrożek gotowat dla Gombrowicza, w: Mrożek w odstonach. 39 opowieści z różnych miejsc i czasów, oprac. Miecznicka M., Kraków.

Gombrowicz W., 1992, Driennik 1967-1969, w: Błoński J., Jarzębski J., red., Kraków.

Lem S., Mrożek S., 2011, Listy 1956-1978, Kraków.

Mrożek S., 2003, Moja zmora, Gombrowicz, w: tegoż: Varia. Życie i inne okoliczności, t. I, Warszawa.

${ }^{6}$ Taki tytuł ma jeden z jego autobiograficznych felietonów. Zob. Mrożek 2003, 189-196. 
Mrożek S., 2004, Baltaz̧ar. Autobiografia, wstęp Nyczek T., Kraków.

Mrożek S., 2010, Dziennik. Tom 1. 1962-1969, Kraków.

Mrożek S., 2012, Dĩiennik. Tom 2. 1970-1979, Kraków.

Mrożek S., 2013, Driennik. Tom 3. 1980-1989, Kraków.

Mrożek S., Skalmowski W., 2007, Listy 1970-2003, wstęp Borowski A., Kraków.

Olejniczak J., red., 2019, Przed i po. Witold Gombrowicz, t. 1-2, Kraków.

Wróbel S., 2015, Polska pozycja depresyjna: od Gombrowicza do Mrożka, Kraków.

Barbara Gutkowska - prof. dr hab., Instytut Literaturoznawstwa, Uniwersytet Śląski w Katowicach, Katowice, Polska.

Literaturoznawca. Autorka artykułów poświęconych prozie XX i XXI wieku, ze szczególnym uwzględnieniem różnych form autobiografizmu - powieści autobiograficznych, dzienników, pamiętników i epistolografii - oraz książek: Powieści Stanisława Dygata. W czasie i przestrzeni życia i marzenia (Katowice 1996), O "Tangu" i "Emigrantach" Sławomira Mrożka (Katowice 1998), Odczytywanie śladów. W kręgu dwudziestowiecznego autobiografizmu (Katowice 2005), Wyzwania i wyznania. Od Andrzeja Trzebińskiego do Sławomira Mrożka (Katowice 2013).

Kontakt: barbara.gutkowska@us.edu.pl 